\title{
RESPONSE OF FORAGE SORGHUM TO WATER AVAILABILITY IN A TYPIC QUARTZIPSAMMENT ${ }^{1}$
}

\author{
ILDEU DE OLIVEIRA ANDRADE JÚNIOR ${ }^{2 *}$, SILVÂNIO RODRIGUES DOS SANTOS ${ }^{3}$, MARCOS KOITI KONDO ${ }^{3}$, \\ POLYANNA MARA DE OLIVEIRA ${ }^{4}$, VICENTE RIBEIRO ROCHA JÚNIOR $^{3}$
}

\begin{abstract}
The objective of this work was to determine the factors of soil water availability (FSWA) that result in the highest agronomic performance of irrigated forage sorghum, with no changes in the plants' chemical-bromatological composition. The experiment was conducted at the Montes Claros State University, Janaúba campus, MG, Brazil, in a Typic Quartzipsamment (Neossolo Flúvico Psamítico - Embrapa) with 59 $\mathrm{mm}$ of soil water storage capacity in the 0.0-0.3 m layer, under drip irrigation. A randomized block design with four replications and a split-plot arrangement was used, consisting of five FSWA $\left(\mathrm{f}_{0.2}=0.20 ; \mathrm{f}_{0.35}=0.35 ; \mathrm{f}_{0.5}=\right.$ $0.50 ; \mathrm{f}_{0.65}=0.65$, and $\mathrm{f}_{0.8}=0.80$ ) in the plots and two simple forage sorghum hybrids (Volumax ${ }^{\circledR}$ and BRS-655) in the split-plots. The evaluations were based on fortnightly measurements of plant height, plant transversal diameter, number of leaves per plant, leaf area index, relative chlorophyll content, stem diameter, panicle length, dry matter yield, water use efficiency, crude protein, mineral matter, acid detergent fiber, neutral detergent fiber, and lignin. The FSWA of 0.20 and 0.35 increased dry matter yield and plant height of the two evaluated sorghum hybrids. The Volumax hybrid presented more crude protein content and acid detergent fiber. The evaluated FSWA did not change the chemical-bromatological composition of the sorghum hybrids.
\end{abstract}

Keywords: Sorghum bicolor L. Irrigation management. Soil water depletion fraction for no stress.

\section{SORGO FORRAGEIRO SUBMETIDO A DISPONIBILIDADE DE ÁGUA EM NEOSSOLO FLÚVICO}

RESUMO - Objetivou-se determinar o fator de disponibilidade hídrica no solo que resultasse ao máximo desempenho agronômico do sorgo forrageiro irrigado, sem alterar sua composição químico-bromatológica. Para isso, utilizou-se uma área experimental do Campus Janaúba da Universidade Estadual de Montes Claros, MG, Brasil, sobre um Neossolo Flúvico Psamítico com capacidade total de armazenamento de água de $59 \mathrm{~mm}$ nos primeiros $0,3 \mathrm{~m}$ de profundidade. O experimento consistiu de 5 fatores de disponibilidade hídrica do solo $\left(\mathrm{f}_{0,2}=0,20 ; \mathrm{f}_{0,35}=0,35 ; \mathrm{f}_{0,5}=0,50 ; \mathrm{f}_{0,65}=0,65\right.$ e $\left.\mathrm{f}_{0,8}=0,80\right)$ e dois híbridos simples de sorgo forrageiro (Volumax ${ }^{\circledR}$ e BRS 655), arranjados no esquema de parcelas subdivididas, com os híbridos nas subparcelas, no delineamento em blocos casualizados, com quatro repetições. A partir da diferenciação, quinzenalmente foram avaliados a altura de planta, diâmetro de colo, diâmetro transversal de planta, número de folhas por planta, índice de área foliar, teor relativo de clorofila, diâmetro de caule, comprimento de panícula, produção de matéria seca, eficiência de uso da água, proteína bruta, cinzas, fibra em detergente ácido, fibra em detergente neutro e lignina. $\mathrm{O}$ fator $\mathrm{f}$ entre 0,20 e 0,35 promove maior produção de matéria seca e altura de plantas nos dois híbridos de sorgo. O híbrido Volumax ${ }^{\circledR}$ apresentou melhores teores de proteína bruta e fibra em detergente ácido. Os fatores f testados não alteraram a composição químico-bromatológica dos híbridos.

Palavras-chave: Sorghum bicolor L. Manejo de irrigação. Fator de disponibilidade hídrica. 


\section{INTRODUCTION}

The reduction of water supply in satisfactory quantity for agricultural production in northern Minas Gerais, Brazil, shows the importance of a proper water use and management for this region to continue producing meat and milk competitively.

Thus, growing of forage plants tolerant to water deficit, such as sorghum (Sorgum bicolor L. Moench), with proper water management has been used. This species has been adapted to edaphoclimatic conditions in semiarid regions; it presents high biomass production, rusticity, and more tolerance to water deficit than maize (ALBUQUERQUE et al., 2010), requiring 450 to $600 \mathrm{~mm}$ of water during its cycle for maximum yield (ASSEFA; STAGGENBORG; PRASAD, 2010).

Therefore, sorghum is widely used as roughage in cattle feed for meat and milk production in northern Minas Gerais, during periods of forage shortage (ALBUQUERQUE et al., 2013).

However, the tolerance of sorghum to water deficit is over short periods of time; its growth and productivity may be affected negatively when it is subjected to prolonged water deficit periods (ASSEFA et al., 2010). Thus, the correct use of irrigation can enhance the production of forage sorghum, as shown by Zwirtes et al. (2015) and Kirchner et al. (2017).

A proper irrigation management for crops requires the establishment of soil water storage limits that allow the water consumption without reducing the crop yield. These limits are established using the factor of soil water availability (FSWA) (factor f), which corresponds to a percentage of total soil water available to plants that does not reduce their productivity, i.e., a point between the minimum soil moisture that causes no water deficit to plants (critical moisture) and the soil field capacity at the effective depth of their root systems (ALLEN et al., 2006; MANTOVANI; BERNARDO; PALARETTI, 2009).

Several studies have been conducted with limitation of soil water availability to plants or application of fractions of the water depth required for the plant cycle (KLOCKE et al., 2012; JAHANZAD et al., 2013; SHER et al., 2013;

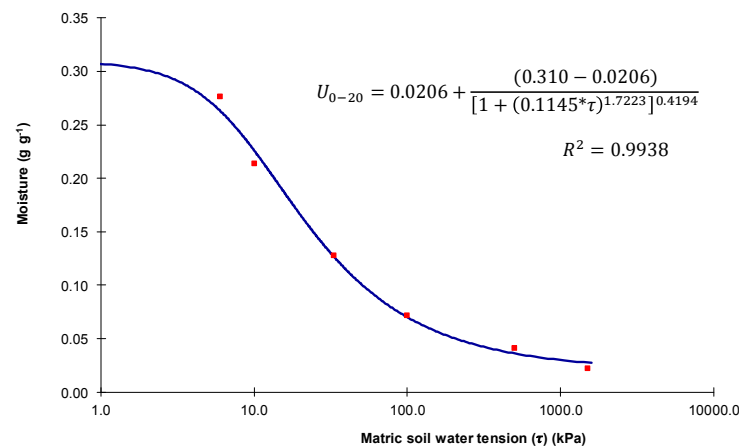

VIEIRA et al., 2015; ZWIRTES et al., 2015). However, no studies determined the factor $f$ for forage sorghum at regional level, or its effects on the agronomic performance and chemicalbromatological composition of this species.

The determination of the factor $f$ requires attention to the soil type used; sandy soils may have less water retention capacity and the water depletion occurs faster, requiring more frequent irrigation. Light-textured soils in Brazil, such as Neossols, had have little relevance to agriculture in the past, even when located in areas that favor mechanization, due to their limitations for management-fertility deficiency, high susceptibility to erosion, groundwater contamination, and water deficiency. Currently, agriculture has been established in these soils due to advances in production systems and agricultural practices, including irrigation (DONAGEMMA et al., 2016).

In this context, the objective of this work was to determine the factors of soil water availability (FSWA) in a Typic Quartzipsamment that result in the highest agronomic and bromatological performance of two irrigated forage sorghum hybrids.

\section{MATERIAL AND METHODS}

The experiment was carried out at the experimental area of the Montes Claros State University (UNIMONTES), Janaúba, state of Minas

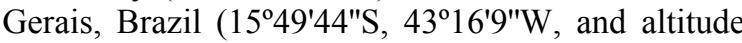
of $544 \mathrm{~m}$ ). The climate of the region is Aw (ALVARES et al., 2013), tropical with dry winter, according to the Köppen classification. The soil of the area was classified as a Typic Quartzipsamment (Neossolo Flúvico Psamítico) (EMBRAPA, 2013), derived from alluvial sediments from the Gorutuba River, with the horizon A overlying directly over horizon $\mathrm{C}$, presenting sandy texture on all horizons up to $1.2 \mathrm{~m}$ depth. The soil had a total water storage capacity of $59 \mathrm{~mm}$ in the 0.0-0.3 m layer (Figure 1), field capacity of $20 \mathrm{kPa}$, and permanent wilting point of $1500 \mathrm{kPa}$, which are related to the higher proportion of medium and fine sand in the sand fraction.

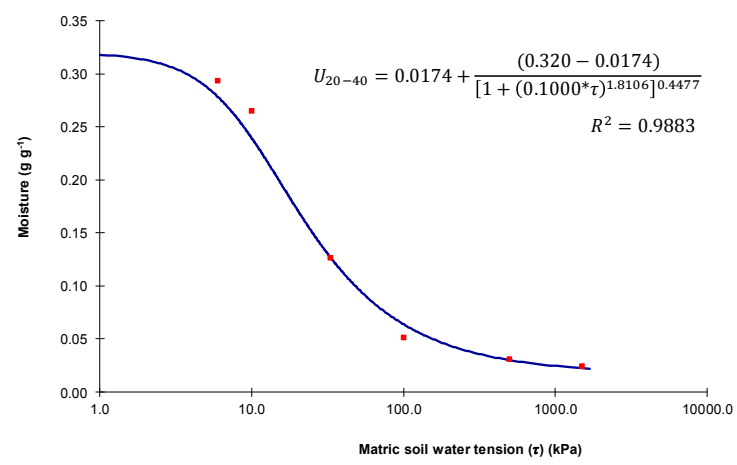

FIGURE 1. Water retention curves of a Typic Quartzipsamment, adjusted by the Van Genuchten model. Soil density equal to $1.39 \mathrm{~g} \mathrm{~cm}^{-3}$. 
Data of insolation, precipitation, and maximum, average, and minimum temperatures during the experiment were collected using an automatic weather station located in the experimental area (Figure 2).

The drip irrigation system used consisted of dripper lines spaced $1.0 \mathrm{~m}$ apart and $0.33 \mathrm{~m}$ between drippers, working at an average flow of $2.56 \mathrm{~L} \mathrm{~h}^{-1}$, pressure of $150 \mathrm{kPa}$, and average application efficiency of $92 \%$ (obtained through 5 evaluations) (MERRIAM; KELLER, 1978; MANTOVANI; BERNARDO; PALARETTI, 2009).

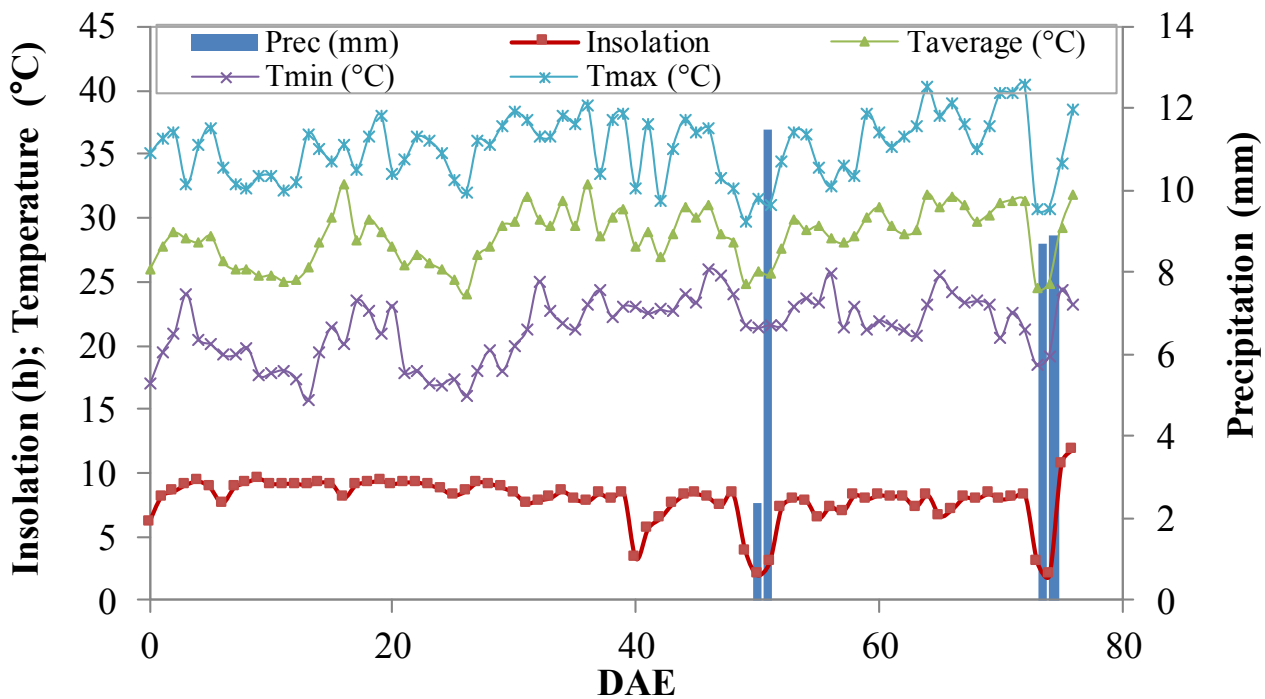

Figure 2. Meteorological data observed during the experimental period (0 to 70 days after emergence - DAE).

A randomized block design with four replications was used, and the treatments were arranged in split plot. The plots consisted of five factors of soil water availability (FSWA) $\left(f_{0.2}=0.20\right.$; $\mathrm{f}_{0.35}=0.35 ; \mathrm{f}_{0.5}=0.50 ; \mathrm{f}_{0.65}=0.65$, and $\left.\mathrm{f}_{0.8}=0.80\right)$, i.e., treatment $\mathrm{f}_{0.2}$ had irrigation when $20 \%$ of the total available soil water had been consumed by the crop, and so on. Plants on treatments $\mathrm{f}_{0.5}, \mathrm{f}_{0.65}$, and $\mathrm{f}_{0.8}$ were subjected to controlled water deficit, since the soil moisture condition reached values below the critical limit (ALLEN et al., 2006). The subplots consisted of two simple forage sorghum hybrids $\left(\right.$ Volumax $^{\circledR}$ and BRS-655) (Table 1). Each subplot had four 4-meter rows of plants; the evaluation area consisted of the two central rows, disregarding $1.0 \mathrm{~m}$ at their ends, i.e., two 2-meter rows, totaling 26 plants in $2 \mathrm{~m}^{2}$ at emergence.

Table 1. Characteristics of the forage sorghum genetic materials used.

\begin{tabular}{|c|c|c|c|c|c|c|}
\hline Hybrid & Genetic Base & Cycle & Silage & Panicle & Height & Supplier \\
\hline BRS-655 & Simple Hybrid & Medium-early & 90-100 days & Semi-open & $250 \mathrm{~cm}$ & Embrapa \\
\hline Volumax & Simple Hybrid & Late & $100-110$ days & Semi-open & $250 \mathrm{~cm}$ & Agroceres \\
\hline
\end{tabular}

*Source: Seed producing companies.

The soil was prepared using a blade harrow/ plow leveler; it was fertilized at five days before sowing, using a mixture of urea, MAP, and potassium chloride $\left(20.0 \mathrm{~kg} \mathrm{ha}^{-1}\right.$ of $\mathrm{N}, 30.0 \mathrm{~kg} \mathrm{ha}^{-1}$ of $\mathrm{P}_{2} \mathrm{O}_{5}$, and $45.0 \mathrm{~kg} \mathrm{ha}^{-1}$ of $\mathrm{K}_{2} \mathrm{O}$ ), according to Alves et al. (1999) and based on soil analysis (Table 2).

The seeds of the forage sorghum hybrids were manually sowed on October 08,2016 , using six to seven seeds per meter in the planting row, for a stand of 120,000 to 140,000 plants $\mathrm{ha}^{-1}$. The soil was irrigated with a $20 \mathrm{~mm}$ water depth two days before sowing, which was divided into two irrigations, reaching the field capacity in the $0.0-0.2 \mathrm{~m}$ layer (Figure 1). Irrigations were performed twice a day to maintain the soil moisture close to field capacity, until the emergence of the plants.

The emergence of more than $50 \%$ of seedlings was observed on August 15, 2016, which was set as day zero for emergence. Then, daily irrigations maintained the soil moisture close to field capacity up to the depth of $0.3 \mathrm{~m}$ (effective root system) until 30 days after emergence (DAE). Soil moisture sensors (Watermark ${ }^{\circledR}$ ) were installed in a plot of each treatment, with evaluations at depths of 
$0.1,0.3,0.5$, and $0.7 \mathrm{~m}$, representing the $0.0-0.2,0.2-$ $0.4,0.4-0.6$, and $0.6-0.8 \mathrm{~m}$ layers, but only the readings from sensors at the depths of 0.1 and $0.3 \mathrm{~m}$ were used to calculate the irrigation water depth. The readings were converted to soil moisture by water retention curves made using local soil samples from each layer (Figure 1).

Two fertigation were performed to complement the soil fertilization up to $30 \mathrm{DAE}$, totaling $160 \mathrm{~kg} \mathrm{ha}^{-1}$ of $\mathrm{N}, 50 \mathrm{~kg} \mathrm{ha}^{-1}$ of $\mathrm{P}_{2} \mathrm{O}_{5}$, and $90 \mathrm{~kg} \mathrm{ha}^{-1} \mathrm{de} \mathrm{K}_{2} \mathrm{O}$ over the crop cycle. Cultural practices were performed according to the need of the crop.

Treatments were changed after $30 \mathrm{DAE}$, with water replenishment calculated based on the soil moisture determined daily at 9 a.m. by the moisture sensors. The irrigation intended to raise the soil moisture from the near minimum limit of water availability (factor $\mathrm{f}$ ) of the treatment to the field capacity in the first $0.3 \mathrm{~m}$ depth. Therefore, the interval between irrigations varied.

Table 2. Chemical and physical attributes of the soil of the experimental area before the implementation of the experiment.

\begin{tabular}{|c|c|c|c|c|c|c|c|c|c|c|c|c|c|}
\hline $\begin{array}{c}\text { Layer } \\
\text { (m) }\end{array}$ & $\begin{array}{l}\mathrm{pH} \\
\mathrm{H}_{2} \mathrm{C}\end{array}$ & & $\begin{array}{l}\mathrm{OM}^{1} \\
\operatorname{dag~kg}^{-1}\end{array}$ & $\mathrm{P}^{2}$ & $\begin{array}{r}\mathrm{K}^{2} \\
\mathrm{mg} \mathrm{dm}-3\end{array}$ & & $\mathrm{Na}^{2}$ & $\mathrm{Ca}^{3}$ & $\mathrm{Mg}^{3}$ & $\begin{array}{c}\mathrm{Al}^{3} \\
\mathrm{cmol}_{\mathrm{c}} \mathrm{dm}^{-3}\end{array}$ & $\mathrm{H}+\mathrm{Al}^{4}$ & $\mathrm{SB}^{5}$ & $\mathrm{CEC}^{6}$ \\
\hline $0-0.2$ & 6.2 & & 0.7 & 39.9 & 142 & & 0.1 & 2.3 & 0.5 & 0 & 1.8 & 3.3 & 5.1 \\
\hline $0.2-0.4$ & 6.4 & & 0.7 & 35.7 & 161 & & 0.1 & 2.5 & 0.9 & 0 & 1.5 & 3.9 & 5.4 \\
\hline $\begin{array}{c}\text { Layer } \\
\text { (m) }\end{array}$ & $\mathrm{BS}^{7}$ & $\mathrm{AS}^{8}$ & $\mathrm{~B}^{9}$ & $\mathrm{Cu}^{2}$ & $\begin{array}{c}\mathrm{Fe}^{2} \\
\mathrm{mg} \mathrm{dm}^{-3}\end{array}$ & $\mathrm{Mn}^{2}$ & $\mathrm{Zn}^{2}$ & \multicolumn{2}{|c|}{$\begin{array}{l}\text { P-rem } \\
\text { mg L L }^{10}\end{array}$} & $\begin{array}{c}\mathrm{EC}^{11} \\
\mathrm{dS} \mathrm{m} \mathrm{m}^{-1}\end{array}$ & Sand* & $\begin{array}{c}\text { Silt* } \\
\text { dag kg-1 }\end{array}$ & Clay* \\
\hline $0-0.2$ & 65 & 0 & 0.2 & 0.8 & 80.9 & 28.2 & 7.9 & \multicolumn{2}{|c|}{47.5} & 0.1 & 86 & 9 & 5 \\
\hline $0.2-0.4$ & 72 & 0 & 0.2 & 0.7 & 84.1 & 34.3 & 5.4 & \multicolumn{2}{|c|}{46.8} & 0.2 & 90 & 5 & 5 \\
\hline
\end{tabular}

${ }^{1}$ organic matter determined by colorimetry; ${ }^{2}$ Extracted by Mehlich $-1 ;{ }^{3}$ Extracted by $\mathrm{KCl} 1 \mathrm{~mol} \mathrm{~L}{ }^{-1}$; Estimator: $\mathrm{pH}$ SMP; ${ }^{5} \mathrm{SB}$ : sum of bases; ${ }^{6} \mathrm{Cation}$ exchange capacity at $\mathrm{pH} 7 ;{ }^{7} \mathrm{BS}$ : base saturation; ${ }^{8} \mathrm{AS}$ : aluminum saturation; ${ }^{9} \mathrm{Extractor}: \mathrm{BaCl}_{2}$; ${ }^{10}$ Remaining phosphorus determined by $\mathrm{P}$ equilibrium solution; ${ }^{11} \mathrm{EC}$ : Electrical conductivity of saturated soil extract at a ratio of 1 (soil):0.5 (water); *(LEMOS; SANTOS; LEMOS, 2012)

Ten plants of each subplot were marked at 29 DAE for growth monitoring and relative chlorophyll content (RCC) and leaf area index (LAI) readings. Plant growth evaluations (stem diameter; plant transversal diameter - perpendicular to the planting row; and number of true leaves per plant), and RCC and LAI readings were performed at 30,45 , and 60 DAE. The RCC was measured with a chlorophyll meter (Soil Plant Analysis Development SPAD$502^{\circledR}$ ), and the LAI with a digital ceptometer (LP-80 Acuppar $^{\circledR}$ ) containing an integrated probe and a microcontroller.

The plants in the evaluation area were cut close to the ground using a machete, tied together, identified, and taken for processing in an electric forage packer for grinding them to particles smaller than $2 \mathrm{~cm}$. Samples were weighed and their fresh matter yield $\left(\mathrm{kg} \mathrm{ha}^{-1}\right)$ were estimated. The percentage of dry matter content (\%) was multiplied by the fresh matter yield to estimate the dry matter yield (DMY).

Water use efficiency (kg of dry matter per $\mathrm{m}^{3}$ ) was calculated by the correlation between DMY and total net irrigation water depth (TWD) as shown in Equation 1,

$$
W U E=\frac{\mathrm{DMY}}{\mathrm{TWD} \times 10}
$$

where DMY is the dry matter yield $\left(\mathrm{kg} \mathrm{ha}^{-1}\right)$ and TWD is the accumulated net irrigation depth + effective rainfall $(\mathrm{mm})$.

Subsamples from the ground samples were properly packaged in paper bags, weighed, and dried in a forced-air circulation oven at $65^{\circ} \mathrm{C}$ for 72 hours. Then, the material was left at room temperature for two hours for stabilization of its weight to determine the percentage of the dry matter, by the division of this weight per its initial weight (TABOSA et al., 2002).

The samples were milled in a Wiley mill and passed through a $2 \mathrm{~mm}$ mesh sieve to determine the dry matter yield (DMY) at $105{ }^{\circ} \mathrm{C}$, crude protein (CP), neutral detergent fiber (NDF), acid detergent fiber (ADF), and mineral matter (MM), according to Detman et al. (2012); and lignin by the sequential method of Van Soest et al. (1991).

The plant growth evaluations considered the mean of 10 plants of each subplot, which were subjected to analysis of variance, considering the split-plot arrangement and the evaluation times. When the F-test was significant up to $p \leq 0.05$, the Tukey's test was applied to compare the evaluation times and the interactions. The F-test was conclusive to compare the sorghum hybrids singly, prioritizing the significant interactions. When the source of variation (factors $\mathrm{f}$ ) was significant in the $\mathrm{F}$ test, regression models were applied to the variables as a function of the factors $f$, based on the significance of the F-test of the regression $(p \leq 0.05)$, coefficient of determination $\left(\mathrm{R}^{2}\right)$, significance of the t-test for the parameters $(p \leq 0.05)$, and capacity of the model to explain the variation evaluated. The data were analyzed using the SAEG 9.1 program (FUNARBE, 2007). 


\section{RESULTS AND DISCUSSION}

The total irrigation water depth applied up to 30 DAE, when the treatments were changed, was $261.7 \mathrm{~mm}$ (Table 3). Three rainfall occurred after 30 DAE (Figure 2), whose total effective water depth was $24.3 \mathrm{~mm}$, and the irrigation water depths applied ranged from 125.9 to $157.7 \mathrm{~mm}$, according to the factor of soil water availability (FSWA) (Table 3). The treatment with $\mathrm{f}_{0.5}$ had irrigation water depths $4 \%$ lower than that with $\mathrm{f}_{0.2}$, and $7 \%$ lower than that with $\mathrm{f}_{0.8}$. The lower the factor $\mathrm{f}$, the higher the irrigation frequency, which were $35 \%$ and $39.4 \%$ higher in the treatment with $\mathrm{f}_{0.2}$ when compared to that with $\mathrm{f}_{0.5}$ and those with $\mathrm{f}_{0.65}$ and $\mathrm{f}_{0.8}$, respectively.

Considering that the irrigations were defined (time and amount) to raise the soil moisture to field capacity, using the soil moisture sensors, it was expected that the total applied water depths would be similar (Table 3), with changes only for their frequency (NI). However, the treatment with $\mathrm{f}_{0.5}$ had the lowest total water depth applied and total time of irrigation because it had one less irrigation than the others, corresponding to $18 \mathrm{~mm}$; this was due to an increase in soil water tensions and also due to the average of the water depths applied in this treatment, which would require an irrigation at one or two days after the end of the irrigation treatments.

A minimum number of irrigations is desirable from an operational point of view, as it would require less labor and electricity consumption. However, long intervals between irrigations reduce soil water, making it difficult for plants to absorb water (VIEIRA et al., 2015), and increasing the risk of percolation due to high water depths needed to raise the soil moisture to field capacity.

Table 3. Irrigation water depths up to 30 days after emergence (DAE) (Initial WD), irrigation water depths after $30 \mathrm{DAE}$ (WD), effective rainfall (ER), total irrigation water depths (Total WD), total irrigation time (Ti), and number of irrigations (NI) in each treatment during the sorghum cycle.

\begin{tabular}{|c|c|c|c|c|c|c|}
\hline \multirow{2}{*}{ Factor $\mathrm{f}$} & Initial WD & WD & ER & Total WD & $\mathrm{Ti}$ & \multirow{2}{*}{ NI } \\
\hline & \multicolumn{4}{|c|}{$\mathrm{mm}$} & hours & \\
\hline 0.20 & 261.7 & 147.0 & 24.3 & 433.0 & 53.28 & 46 \\
\hline 0.35 & 261.7 & 139.8 & 24.3 & 425.8 & 52.40 & 39 \\
\hline 0.50 & 261.7 & 125.9 & 24.3 & 411.9 & 50.43 & 34 \\
\hline 0.65 & 261.7 & 136.7 & 24.3 & 422.7 & 51.93 & 33 \\
\hline 0.80 & 261.7 & 157.7 & 24.3 & 443.7 & 54.88 & 33 \\
\hline
\end{tabular}

The interaction between the factors $f$ and evaluation times was not significant for any of the variables evaluated throughout the cycles of the studied sorghum hybrids (Table 4). The factors $\mathrm{f}$ had isolated significant effect on dry matter yield (DMY) and water use efficiency (WUE). The sorghum hybrids, as source of variation, had significant effect on number of leaves (NL) per plant, plant transversal diameter (PTD), leaf area index (LAI), and relative chlorophyll content (RCC). However, all variables evaluated presented changes in the evaluations over time (Table 4)

The stem diameter (SD) of the sorghum hybrids presented difference at 45 and 60 DAE; the Volumax hybrid presented higher SD than BRS-655 in all evaluations (Table 5). Both hybrids had high stem diameter at 45 DAE (1.6 for BRS-655; $1.8 \mathrm{~cm}$ for Volumax).

Albuquerque et al. (2013) evaluated the agronomic characteristics of forage sorghum in the semiarid region of Minas Gerais and found SDs of $1.09 \mathrm{~cm}$ for Volumax and $1.13 \mathrm{~cm}$ for BRS 610, with no difference between the hybrids, which were lower than the SDs found in the present study. These results denote the variability in agronomic performance of forage sorghum hybrids under different management conditions (NEVES et al., 2014). Plant size and stem diameter present direct positive correlation with fresh and dry matter yields and photoassimilate accumulation (FREITAS et al., 2012; ALBUQUERQUE et al., 2013). 
Table 4. Analysis of variance for number of true leaves per plant (NL), stem diameter (SD; $\mathrm{cm})$, plant transversal diameter $(\mathrm{PTD} ; \mathrm{cm})$, leaf area index (LAI), relative chlorophyll content (RCC), panicle length (PL; cm), dry matter yield (DMY, kg $\mathrm{ha}^{-1}$ ), and water use efficiency (WUE, $\mathrm{kg}$ of dry matter per $\mathrm{m}^{-3}$ ) of two forage sorghum hybrids subjected to five water irrigation depths during their cycle.

\begin{tabular}{|c|c|c|c|c|c|c|c|c|c|}
\hline SV & $\overline{D F}$ & $\mathrm{NL}$ & SD & PTD & LAI & $\overline{\mathrm{RCC}}$ & $\overline{\mathrm{PL}}$ & $\overline{\mathrm{DMY}}$ & WUE \\
\hline Blocks & 3 & $9.9^{* *}$ & $2.14^{* * *}$ & $1217.1^{* *}$ & $2.024^{\mathrm{ns}}$ & $1679.7^{* *}$ & $54.0^{* *}$ & $0.212^{* *}$ & $1.177^{* *}$ \\
\hline Factors $\mathrm{f}(\mathrm{f})$ & 4 & $0.9^{\mathrm{ns}}$ & $0.629^{\mathrm{ns}}$ & $94.1^{\mathrm{ns}}$ & $2.805^{\mathrm{ns}}$ & $190.0^{\mathrm{ns}}$ & $2.1^{\mathrm{ns}}$ & $0.160^{*}$ & $0.86^{*}$ \\
\hline Residue A & 12 & 1.0 & 0.111 & 151.9 & 2.022 & 126.9 & 1.8 & 3529935 & 0.197 \\
\hline Hybrids (HIB) & 1 & $86.9^{* *}$ & $0.91^{\mathrm{ns}}$ & $785.9^{* *}$ & $3.89^{* *}$ & $1032.76^{* *}$ & $89.7^{\mathrm{ns}}$ & $5017597^{\mathrm{ns}}$ & 0.257 \\
\hline $\mathrm{f} \times \mathrm{HIB}$ & 4 & $0.2^{\mathrm{ns}}$ & $0.184^{\mathrm{ns}}$ & $35.82^{\mathrm{ns}}$ & $0.294^{\mathrm{ns}}$ & $30.263^{\mathrm{ns}}$ & $1.26^{\mathrm{ns}}$ & $3580225^{\mathrm{ns}}$ & 0.193 \\
\hline Residue B & 15 & 0.2 & 0.209 & 17.5 & 0.262 & 91.3 & 2.2 & 6109566 & 0.326 \\
\hline Time (DAE) & 2 & $60.7^{* *}$ & $0.811^{* *}$ & $8297.1^{* *}$ & $7.59^{* *}$ & $15370.9^{* *}$ & - & - & - \\
\hline $\mathrm{f} \times \mathrm{DAE}$ & 8 & $0.5^{\mathrm{ns}}$ & $0.473^{\mathrm{ns}}$ & $56.5^{\mathrm{ns}}$ & $0.76^{\mathrm{ns}}$ & $75.69^{\text {ns }}$ & - & - & - \\
\hline $\mathrm{HIB} \times \mathrm{DAE}$ & 2 & $10.6^{* *}$ & $0.720^{*}$ & $99.42^{\mathrm{ns}}$ & $1.771^{*}$ & $225.2^{\mathrm{ns}}$ & - & - & - \\
\hline $\mathrm{f} x \mathrm{HIB} \times \mathrm{DAE}$ & 8 & $0.6^{\mathrm{ns}}$ & $0.709^{\mathrm{ns}}$ & $12.21^{\mathrm{ns}}$ & $0.472^{\mathrm{ns}}$ & $36.1^{\mathrm{ns}}$ & - & - & - \\
\hline Residue C & 60 & 0.487 & 0.186 & 41.39 & 0.50 & 236.215 & - & - & - \\
\hline Mean & & 6.41 & 1.56 & 68.20 & 2.41 & 76.21 & 24.79 & 9573.1 & 2.24 \\
\hline CV $1(\%)$ & & 9.445 & 8.731 & 9.44 & 28.95 & 20.16 & 5.41 & 19.62 & 19.81 \\
\hline CV $2(\%)$ & & 7.25 & 29.23 & 6.13 & 21.23 & 12.53 & 6.0 & 25.82 & 25.48 \\
\hline CV $3(\%)$ & & 10.88 & 27.57 & 9.43 & 29.34 & 20.16 & - & - & - \\
\hline
\end{tabular}

$\mathrm{SV}=$ Source of variation; $\mathrm{DF}=$ degrees of freedom; ${ }^{*}=$ Significant at $5 \%,{ }^{* *}=$ significant at $1 \%$, and ${ }^{\mathrm{ns}}=$ not significant by the $\mathrm{F}$ test.

The results for NL of the hybrids were different in all evaluated times; Volumax had the highest NL in all evaluations (Table 5). The highest NL were found at 45 DAE (8.4 for Volumax; 6.7 for BRS-655). The highest NL of Volumax resulted in a larger surface area to intercept solar radiation. However, the Volumax hybrid presented the highest LAI mean at 60 DAE (Table 6), when the BRS-655 was already reaching the harvest point because it is a semi-early hybrid (Table 1); the hybrids presented significant difference only in this evaluation time.

Moreover, despite Volumax presented higher LAI in the three evaluation times, the significant difference found only at 60 DAE indicates that the hybrids had similar leaf area development until the beginning of the reproductive stage (45 DAE) and that the BRS-655 plants possibly compensate their smaller NL. However, this compensation decreases after the reproductive stage, with the differentiation of the apical meristem in an inflorescence, which is normal due to the fall of senescent leaves at the end of the plant cycle. A decrease in LAI is only harmful when occurring at plant growth and development stages. It is an irreversible morphological adaptation in determinate-growth crops, such as forage sorghum, which decreases the interception and absorption of photosynthetically active solar radiation and, consequently, the carbohydrate production. 
Table 5. Means of plant heights $(\mathrm{cm})$, stem diameter $(\mathrm{cm})$, number of leaves, and leaf area index of two forage sorghum hybrids, in three post-emergence evaluations (DAE).

\begin{tabular}{|c|c|c|c|}
\hline \multirow{2}{*}{ Hybrids } & \multicolumn{3}{|c|}{$\overline{D A E}$} \\
\hline & 30 & 45 & 60 \\
\hline \multicolumn{4}{|c|}{ Plant Height } \\
\hline BRS-655 & $67.4 \mathrm{aC}$ & $108.8 \mathrm{aB}$ & $139.2 \mathrm{bA}$ \\
\hline Volumax & $65.6 \mathrm{aC}$ & $106.2 \mathrm{aB}$ & $150.5 \mathrm{bA}$ \\
\hline \multicolumn{4}{|c|}{ Stem diameter } \\
\hline BRS-655 & $1.4 \mathrm{aB}$ & $1.6 \mathrm{bA}$ & $1.5 \mathrm{bB}$ \\
\hline Volumax & $1.5 \mathrm{aC}$ & $1.8 \mathrm{aA}$ & $1.7 \mathrm{aB}$ \\
\hline \multicolumn{4}{|c|}{ Number of leaves } \\
\hline BRS-655 & $4.8 \mathrm{bB}$ & $6.7 \mathrm{bA}$ & $5.2 \mathrm{bB}$ \\
\hline Volumax & $5.5 \mathrm{aB}$ & $8.4 \mathrm{aA}$ & $7.9 \mathrm{aA}$ \\
\hline \multicolumn{4}{|c|}{ Leaf area index } \\
\hline BRS-655 & $1.9 \mathrm{aB}$ & $2.5 \mathrm{aA}$ & $2.4 \mathrm{bA}$ \\
\hline Volumax & $2.0 \mathrm{aC}$ & $2.6 \mathrm{aB}$ & $3.2 \mathrm{aA}$ \\
\hline
\end{tabular}

Means followed by the same lowercase letter in the column and uppercase letter in the row do not differ by the Tukey's test at $5 \%$ significance.

Despite the BRS-655 presented lower means for NL, LAI, and PTD when compared to Volumax, it was more efficient in $\mathrm{N}$ assimilation, presenting higher RCC (Table 6). RCC is indirectly related to $\mathrm{N}$ content in plant leaves, since $\mathrm{N}$ is part of and participates in the synthesis of the chlorophyll molecule (PORTO et al., 2011). Therefore, BRS-655 presented higher photosynthetic capacity due to the $\mathrm{N}$ assimilation of its leaves.

Table 6. Number of leaves, leaf area index, plant transversal diameter $(\mathrm{cm})$, and relative chlorophyll content of two forage sorghum hybrids.

\begin{tabular}{|c|c|c|}
\hline \multirow{2}{*}{ Variable } & \multicolumn{2}{|c|}{ Hybrid } \\
\hline & BRS-655 & Volumax \\
\hline Number of leaves & $5.6 \mathrm{~B}$ & $7.3 \mathrm{~A}$ \\
\hline Leaf area index & $2.2 \mathrm{~B}$ & $2.6 \mathrm{~A}$ \\
\hline Plant transversal diameter & $65.6 \mathrm{~B}$ & $70.7 \mathrm{~A}$ \\
\hline Relative chlorophyll content & $79.1 \mathrm{~A}$ & $73.3 \mathrm{~B}$ \\
\hline
\end{tabular}

Means followed by the same letter in the rows do not differ by the Tukey's test at $p \leq 0.05$.

The DMY of the sorghum hybrids decreased as the FSWA (factor f) was increased. Thus, increasing the interval between irrigations resulted in water deficits, which hindered plant development. The highest DMY results were obtained in the treatments with $\mathrm{f}_{0.2}$ and $\mathrm{f}_{0.35}$, which had shorter intervals between irrigations (Figure 3). 
DMY of forage sorghum is related to plant height; large plants produce approximately $15 \mathrm{Mg} \mathrm{ha}^{-1}$ in a single cut (EMBRAPA, 2009). Thus, the DMY found in the treatments with $\mathrm{f}_{0.2}$ and $\mathrm{f}_{0.35}$ were similar to those reported in the literature. However, DMY presented decreases and differences from the commonly found DMY results when increasing the factor $\mathrm{f}$, especially the factor $\mathrm{f}_{0.8}$ (Figure 3 ).

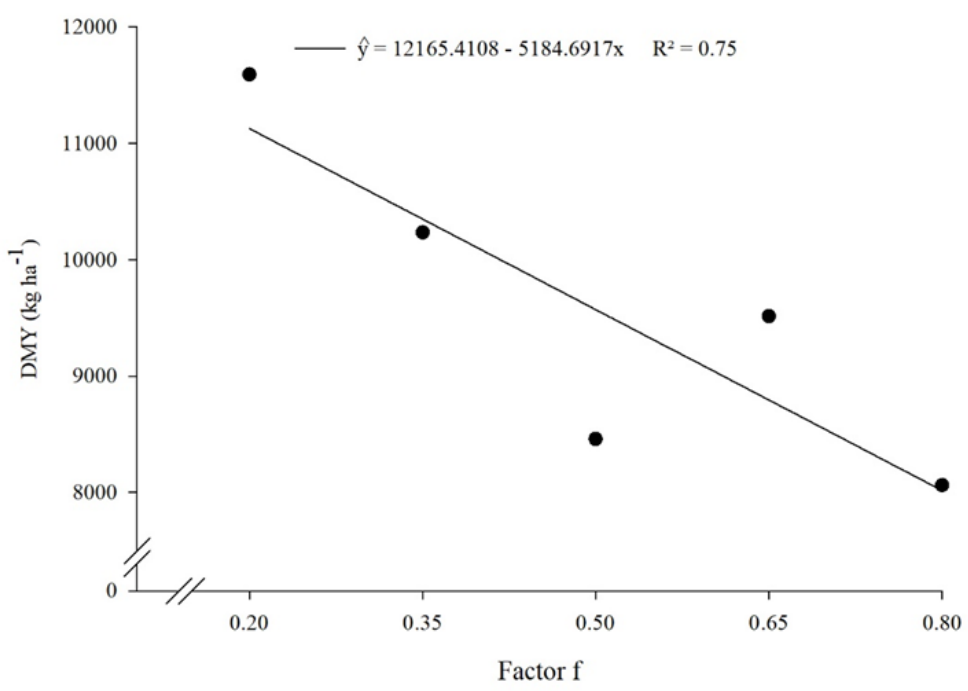

Figure 3. Dry matter yield (DMY) of forage sorghum hybrids subjected to different factors of soil water availability (Factor f).

These results indicate that the DMY of sorghum is directly related to soil water availability - the negative effects on DMY are more pronounced as it decreases (ALBUQUERQUE; MENDES, 2011; ZWIRTES et al., 2015). Water deficit results in stomatal closure, limits nutrient absorption, and reduces photosynthetic efficiency, which can negatively affect the crop yield (SILVA et al., 2011). Vieira et al. (2015) also found decreases in sugarcane yield as irrigation was managed with longer irrigation intervals due to higher FSWA.

The WUE, which expresses the dry matter yielded per amount of water supplied, presented a linear decrease as the factor $\mathrm{f}$ was increased (Figure 4). The WUE in the treatments with $\mathrm{f}_{0.2}$ and $\mathrm{f}_{0.8}$ was higher for the evaluated hybrids, approximately 2.7 and $2.4 \mathrm{~kg}$ of dry matter per $\mathrm{m}^{-3}$, respectively. The treatments with $\mathrm{f}_{0.2}$ and $\mathrm{f}_{0.8}$ also resulted in higher dry matter yields; thus, these factors can be recommended for sorghum crops under similar conditions to those of the present study. The other factors $\left(\mathrm{f}_{0.5}, \mathrm{f}_{0.65}\right.$, and $\left.\mathrm{f}_{0.8}\right)$ presented lower WUE, with $\mathrm{f}_{0.8}$ presenting the lowest (approximately $1.8 \mathrm{~kg}$ of dry matter $\mathrm{m}^{-3}$ ).

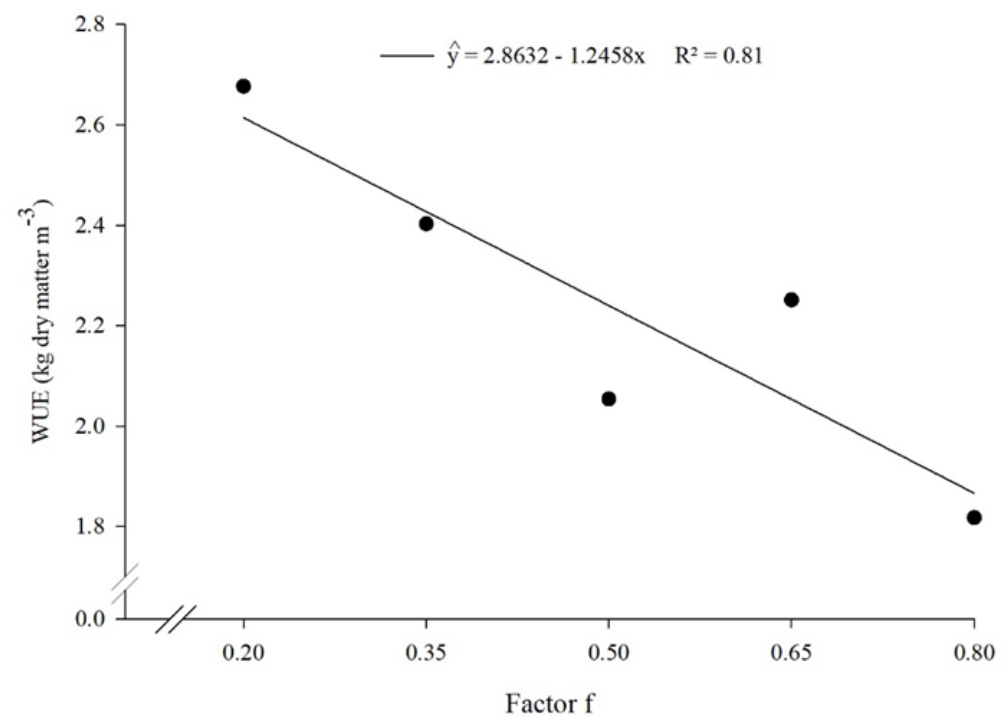

Figure 4. Water use efficiency (WUE) of forage sorghum hybrids subjected to different factors of soil water availability (Factor f). 
Tabosa et al. (2002) evaluated 20 forage sorghum cultivars in different agroecological environments in the states of Pernambuco and Alagoas, Brazil, and found that DMY and WUE combined are suitable for the selection of forage sorghum materials only for semiarid conditions. According to Hanks (1983), the WUE variation is often the basis of genetic improvement for yield under low soil moisture conditions. For regions with water scarcity, as the Brazilian semiarid region, Boyer (1991) indicates several methods that can be used for increasing the plants' DMY, WUE, and resistance to drought. Thus, the results show that a $f$ factor between 0.20 and 0.35 can be recommended for the studied hybrids under the conditions of the present experiment, differing from the recommendations found in the literature, which range from 0.50 to 0.55 (ALLEN et al., 2006; BERNARDO; SOARES; MANTOVANI, 2006; MANTOVANI; BERNARDO; PALARETTI, 2009).

The FSWA applied during the cycle of the evaluated sorghum hybrids caused no changes in their chemical-bromatological composition (Table 7). However, the hybrids affected the crude protein $(p<0.01)$ and acid detergent fiber $(p<0.05)$.

Table 7. Analysis of variance for dry matter yield (DMY; \%), crude protein (CP; \%), mineral matter (MM; \%), neutral detergent fiber (NDF; \%), acid detergent fiber (ADF; \%), and lignin (LG; \%) of two forage sorghum hybrids subjected to five factors of soil water availability (Factor f).

\begin{tabular}{|c|c|c|c|c|c|c|c|}
\hline \multirow{2}{*}{ SV } & \multirow{2}{*}{$\mathrm{DF}$} & \multicolumn{6}{|c|}{ Mean Square } \\
\hline & & DMY & $\mathrm{CP}$ & MM & $\mathrm{NDF}$ & $\overline{\mathrm{ADF}}$ & $\overline{L G}$ \\
\hline Blocks & 3 & $69.56^{*}$ & $2.88^{\mathrm{ns}}$ & $1.35^{\mathrm{ns}}$ & $16.89^{\mathrm{ns}}$ & $6.48^{\mathrm{ns}}$ & $0.19^{\mathrm{ns}}$ \\
\hline Factor (f) & 4 & $10.17^{\mathrm{ns}}$ & $0.71^{\mathrm{ns}}$ & $2.06^{\mathrm{ns}}$ & $5.49^{\mathrm{ns}}$ & $66.11^{\mathrm{ns}}$ & $0.74^{\mathrm{ns}}$ \\
\hline Residue A & 12 & 21.02 & 2.39 & 2.12 & 43.06 & 31.64 & 0.44 \\
\hline Hybrids (HIB) & 1 & $20.04^{\mathrm{ns}}$ & $27.18^{* *}$ & $0.09^{\mathrm{ns}}$ & $79.69^{\text {ns }}$ & $101.85^{*}$ & $0.19^{\text {ns }}$ \\
\hline fx HYB & 4 & $37.12^{\mathrm{ns}}$ & $1.36^{\mathrm{ns}}$ & $1.22^{\mathrm{ns}}$ & $76.67^{\mathrm{ns}}$ & $36.85^{\mathrm{ns}}$ & $0.19^{\text {ns }}$ \\
\hline Residue B & 15 & 26.68 & 1.98 & 1.39 & 88.47 & 17.65 & 0.77 \\
\hline Mean & & 35.9 & 6.6 & 8.3 & 61.7 & 30.3 & 5.4 \\
\hline CV $1(\%)$ & & 12.76 & 23.24 & 17.51 & 10.63 & 18.58 & 12.34 \\
\hline CV $2(\%)$ & & 14.38 & 21.13 & 14.18 & 15.24 & 13.88 & 16.39 \\
\hline
\end{tabular}

$\mathrm{SV}=$ Source of variation; DF $=$ degrees of freedom; ${ }^{*}=$ Significant at $5 \%,{ }^{* *}=$ significant at $1 \%$, and ${ }^{\mathrm{ns}}=$ not significant by the $\mathrm{F}$ test.

The Volumax hybrid presented $29.3 \%$ more crude protein $(\mathrm{CP})$ and $10 \%$ less acid detergent fiber (ADF) than the BRS-655 (Table 8). These results are advantageous for Volumax sorghum hybrid, since $7 \% \mathrm{CP}$ is the minimum recommended to meet the nitrogen requirements of the rumen flora to ensure an adequate fermentation (SILVEIRA et al., 2009). In addition, a low ADF indicates low proportion of lignin (indigestible fiber fraction), denoting a forage with high energy value, since the lower the ADF, the higher the energy value of the forage (SKONIESKI et al., 2010).

The number of leaves in the reproductive stage (60 DAE) of the Volumax hybrid was higher (Table 5), resulting in a higher leaf to stem ratio than that of the BRS-655. This may explain the different $\mathrm{CP}$ and ADF between the hybrids. The results of $\mathrm{CP}$ and ADF were similar to those found in the literature, with differences between the genetic materials, and between stem, leaves, and panicle (NEUMANN; RESTLE; ALVES FILHO, 2002; PEDREIRA et al., 2003; GOMES; PITOMBEIRA; NEIVA, 2006; SILVA et al., 2012).

Sorghum is a roughage feed (fibrous and with low protein content); thus, variations in $\mathrm{CP}$ and $\mathrm{ADF}$ between hybrids are important, since increases in $\mathrm{CP}$ and decreases in ADF improve the weight gain and milk yield of ruminants, mainly during pasture shortage periods and in the dry season. 
Table 8. Crude protein (CP; \%) and acid detergent fiber (ADF; \%) of two forage sorghum hybrids.

\begin{tabular}{|c|c|c|}
\hline \multirow{2}{*}{ Variable } & \multicolumn{2}{|c|}{ Hybrid } \\
\hline & BRS-655 & Volumax \\
\hline $\mathrm{CP}$ & $5.8 \mathrm{~B}$ & $7.5 \mathrm{~A}$ \\
\hline $\mathrm{ADF}$ & $31.9 \mathrm{~A}$ & $28.7 \mathrm{~B}$ \\
\hline
\end{tabular}

Means followed by the same letter in the row do not differ by the $\mathrm{F}$ test at $5 \%$ significance.

\section{CONCLUSIONS}

The BRS-655 sorghum hybrid had higher relative chlorophyll content, lower number of leaves and leaf area index, and smaller plant transversal diameter than the Volumax hybrid. The factors of soil water availability (factor f) of 0.20 and 0.35 applied to the Typic Quartzipsamment (Neossolo Flúvico Psamítico - Embrapa) resulted in the highest dry matter yield and plant height for the two evaluated sorghum hybrids (BRS-655 and Volumax). The factors $\mathrm{f}$ studied did not change the chemicalbromatological composition of the two evaluated sorghum hybrids.

\section{ACKNOWLEDGEMENTS}

The authors thank the Foundation for Research Support of the State of Minas Gerais (FAPEMIG) and the Brazilian Coordination for the Improvement of Higher Education Personnel (CAPES) for their financial support and scholarships.

\section{REFERENCES}

ALBUQUERQUE, C. J. B. et al. Espaçamento reduzido para o cultivo do sorgo granífero no sistema irrigado e em sequeiro, Pesquisa Aplicada \& Agrotecnologia, v. 3, n. 2, p. 1-16, 2010.

ALBUQUERQUE, C. J. B. et al. Características agronômicas e bromatológicas dos components vegetativos de genótipos de sorgo forrageiro em Minas Gerais. Revista Brasileira de Milho e Sorgo, v. 12, n. 2, p. 164-182, 2013.

ALBUQUERQUE, C. J. B.; MENDES, M. C. Época de semeadura do sorgo forrageiro em duas localidades do estado de Minas Gerais. Revista Brasileira de Tecnologia Aplicada nas Ciências Agrárias, v. 4, n. 1, p. 116-134, 2011.

ALLEN, R. G. et al. Evapotranspiración del cultivo. Guias para la determinación de los requerimientos de agua de los cultivos. Rome. FAO, 2006. 320 p.

ALVARES, C. A. et al. Köppen's climate classification map for Brazil. Meteorologische Zeitschrift, v. 22, n. 6, p. 711-728, 2013. Disponível em: <http://dx.doi.org/10.1127/09412948/2013/0507>. Acesso em: 31 jan. 2019.

ALVES, V. M. C. et al. Sorgo. In: COMISSÃO DE FERTILIDADE DO SOLO DO ESTADO DE MINAS GERAIS (CFSEMG). RIBEIRO, A. C.; GUIMARÃES, P. T. G.; ALVAREZ V., V. H. (eds.). Recomendações para o uso de corretivos e fertilizantes em Minas Gerais. 5 ${ }^{\mathbf{a}}$ Aproximação. Viçosa, 1999. cap. 18, p. 317-318.

ASSEFA, Y.; STAGGENBORG. S. A.; PRASAD, P. V. V. Grain sorghum water requeriment and responses to drought stress: A review. CROP MANAGEMENT, Minnesota, 2010. Disponível em: <http: //www.plantmanagementnetwork.org/ pub/cm/review/2010/water/>. Acesso em: 02 de Abr. de 2017.

BERNARDO, S.; SOARES, A. A.; MANTOVANI, E. C. Manual de irrigação. 8 ed. Viçosa, MG. UFV, 2006. 625 p.

BOYER, J. S. Mechanisms for obtaining water use efficiency and drought resistance. In: SIMPOSIUM ON PLANT BREEDING IN THE 1990s, 1991, Raleigh. Plant breeding in the 1990s Proceedings... Wallingford, UK: CAB Internacional, 1992, p. 181-200.

DETMAN, E. et al. Métodos para análises de alimentos. Visconde do rio Branco, MG: Suprema, 2012. 214 p.

DONAGEMMA, G. K. et al. Caracterização, potencial agrícola e perspectivas de manejo de solos leves no Brasil. Pesquisa Agropecuária Brasileira, v. 51, n. 9, p. 1003-1020, 2016.

EMPRESA BRASILEIRA DE PESQUISA AGROPECUÁRIA - EMBRAPA. Sistemas de Produção, Versão Eletrônica - 5 ${ }^{\mathbf{a}}$ edição Set./2009 
Produção de sorgo.

EMPRESA BRASILEIRA DE PESQUISA AGROPECUÁRIA - EMBRAPA. Centro Nacional de Pesquisa de Solos. Sistema brasileiro de classificação de solos. 3. ed. Brasília, DF: Embrapa, 2013. 353 p.

EVETT, S. R. Lower Limits of Crop Water Use in Three Soil Textural Classes, Soil Science Society of America Journal, v. 76, n. 2, p. 607-616, 2012.

FUNARBE, F. A. B. SAEG-Sistema para análises estatísticas, versão 9.1. Viçosa, MG: UFV, 2007.

FREITAS, G. A. et al. Adubação orgânica no sulco de plantio e sua influência no desenvolvimento do sorgo. Journal of Biotechnology and Biodiversity, v. 3, n. 1, p. 61-67, 2012.

GOMES, S. O.; PITOMBEIRA, J. B.; NEIVA, J. N. M. Comportamento agronômico e composição químico-bromatológico de cultivares de sorgo forrageiro no Estado do Ceará. Revista Ciência Agronômica, v. 37, n. 2, p. 221-227, 2006.

HANKS, R. J. Yield and water use relationships. In: TAYLOR, H. M.; JORDAM, W. R.; SINCLAIR, T. $\mathrm{R}$. (Eds.) Limitations to efficient water use in crop production. Madison: American Society of Agronomy, 1983. p. 393-411.

JAHANZAD, E. et al. Response of new and a commonly grown forage sorghum cultivar to limited irrigation and planting density. Agricultural Water Mannagement, v. 117, n. 31, p. 62-69, 2013.

KIRCHNER, J. H. et al. Variation of leaf area index of the forage sorghum under different irrigation depths in dynamic of cuts. African Journal of Agricultural Research, v. 12, n. 2, p. 111-124, 2017.

KLOCKE, N. L. et al. Sorghum yield response to déficit irrigation. American Society of Agricultural and Biological Enginees, v. 55, n. 3, p. 947-955, 2012.

LEMOS, L. M. C.; SANTOS, S. R.; LEMOS, J. P. Crescimento do meloeiro Cantaloupe sob manejo de irrigação por gotejamento em Janaúba, Minas Gerais.

Revista Ceres, v. 59, n. 5, p. 614-623, 2012.

MANTOVANI, E, C.; BERNARDO, S.; PALARETTI, L. F. Irrigação - Princípios e Métodos. 3. ed. Viçosa, MG: UFV, 2009. 355 p.

MERRIAM, J. L.; KELLER, J. Farm irrigation system evaluation: A guide for management. Logan: Utah State University, 1978. 271 p.
NEUMANN, M.; RESTLE, J.; ALVES FILHO, D. C. et al. Avaliação do valor nutritivo de planta e da silagem de diferentes híbridos de sorgo (Sorghum bicolor, L. Moench). Revista Brasileira de Zootecnia, v. 31, n. 1, p. 293-301, 2002.

NEVES, A. L. A. et al. Agronomic Characteristics of Sorghum Cultivars for Silage Production in the Agreste of Pernambuco State. Revista Brasileira de Milho e Sorgo, v. 13, n. 3, p. 382-390, 2014.

PEDREIRA, M. S. et al. Características agronômicas e composição química de oito híbridos de sorgo (Sorghum bicolor (L.) MOENCH). Revista Brasileira de Zootecnia, v. 32, n. 5, p. 1083-1092, 2003.

PORTO, M. L. et al. Índice SPAD para o diagnóstico do estado de nitrogênio na cultura da abobrinha. Horticultura Brasileira, v. 29, n. 3, p. 311-315, 2011

SHER, A. et al. Growth Response and Plant Water Status in Forage Sorghum [Sorghum bicolor (L.) Moench] Cultivars Subjected to Decreasing Levels of Soil Moisture. Australian Journal of Crop Science, v.7, n. 6, p. 801-808, 2013.

SILVA, T. C. et al. Agronomic Divergence of Sorghum Hybrids for Silage yield in the Semiarid Region of Paraíba. Revista Brasileira de Zootecnia, v. 40, n. 9, p. 1886-1893, 2011.

SILVA, T. C. et al. Divergence of the fermentative and bromatological characteristis of 25 sorghum hybrid silages. Revista Brasileira de Zootecnia, v. 41, n. 5, p. 1127-1133, 2012.

SILVEIRA, R. N. et al. Influência do nitrogênio degradável no rúmen sobre a degradabilidade in situ, os parâmetros ruminais e a eficiência de síntese microbiana em novilhos alimentados com cana-deaçúcar. Revista Brasileira de Zootecnia, v. 38, n. 3, p. $570-579,2009$.

SKONIESKI, F. R. et al. Produção, caracterização nutricional e fermentativa de silagem de sorgo forrageiro e sorgo duplo propósito. Acta Scientiarum Animal Science, v. 32, n. 1, p. 27-32, 2010.

TABOSA, J. N. et al. Comportamento de cultivares de sorgo forrageiro em diferentes ambientes agroecológicos dos estados de Pernambuco e Alagoas. Revista Brasileira de Milho e Sorgo, v. 1, n. 2, p. 47-58, 2002.

VAN SOEST, P. J.; ROBERTSON, J .B.; LEWIS, B. A. Methods for dietary fiber, neutral detergent fiber, and nonstarch polysaccharides in relation to 
animal nutrition. Journal of Dairy Science, v. 74, n. 10, p. 3583-3597, 1991.

VIEIRA, G. H. S. et al. Lâminas de irrigação em cana-de-açúcar para diferentes condições de disponibilidade hídrica. Irriga \& Inovagri, v. 1, n. 2, p. 137-148, 2015.

ZWIRTES, A. L. et al. Desempenho produtivo e retorno econômico da cultura do sorgo submetida à irrigação deficitária. Revista Engenharia Agrícola, v. 35 , n. 4 , p. 676-688, 2015. 